УДК 330.341.1(045)

DOI: $10.15673 /$ fie.v10i3.1062

\author{
Коліщук O.B. \\ аспірант \\ кафедра економіки та міжнародних економічних відносин \\ Черкаський національний університет імені Богдана Хмельницького \\ бульвар Шевченка, 81, Черкаси, Черкаська область, 18000 \\ E-mail: olenakolischuk@gmail.com
}

\title{
АНАЛІЗ КЛАСИФІКАЦІЙ ІННОВАЦІЙ ЗА РІВНЕМ НОВИЗНИ
}

У статті розглянуті види класифікацій інновацій в залежності від рівня новизни. Проаналізовано основні підходи класифікації інновацій вітчизняними і зарубіжними дослідниками. Зокрема, розглянуто класифікації інновацій за роллю в реалізації цілей, за значенням для реального напрямку діяльності, за інтенсивністю інноваційних змін, за рівнем об'єктивного сприйняття, за причинами виникнення, за рівнем новизни, за інноваційним потенціалом, за новизною місця впровадження та за характером до свого попередника. Визначено основні чинники, які лягли в основу згаданих класифікацій, аргументований висновок, що в основі перерахованих видів класифікацій знаходиться модель класифікації, запропонована німецьким вченим Г. Меншем, яка є найбільш об'єктивною і уніфікованою і дозволяє використовувати її на всіх етапах життєвого циклу інновацій з метою прискорення процесу визначення рівнів інновацій в залежності від їх новизни і можливості практичного втілення. Вперше надано єдиний підхід поєднання більше десятка існуючих класифікацій інновацій в основі яких є підхід запропонований Г. Меншем. Використання єдиного підходу щодо класифікації інновацій за рівнем новизни має практичне значення з метою пришвидшення класифікації інновацій для прийняття оперативних управлінських рішень. В статті надано єдину класифікацію інновацій, що дає можливість класифікувати інновації за рівнем новизни, за видом об'єкта, за місцем в системі підприємства, за змістом діяльності, за причинами виникнення, за географічним чинником, за частотою застосування, за напрямом реалізації, за фрормою, за рівнем планування, за суб'єктом створення, за швидкістю поширення, за масовістю використання, за результативністю, за характером задоволення потреб споживачів та за призначенням інновацій.

Ключові слова: інновація, класифікація інновацій, класифікаційна ознака, базові інновації, поліпшуючі інновації, псевдоінновації.

This work is licensed under a Creative Commons Attribution 4.0 International License http://creativecommons.org/licenses/by/4.0/

Постановка проблеми та їі зв'язок 3 важливими науковими та практичними завданнями. Проблеми науково-методологічного рівня пов'язані 3 різним тлумаченням поняття «інновація» та відсутністю єдиної класифікації інновацій, що ускладнює процес аналізу і порівняння інновацій для управлінських та статистичних цілей, перешкоджає порівнянню та аналізу інновацій у світовому масштабі. Запропоновано єдиний підхід щодо виокремлення інновацій за рівнем новизни за поділом Г. Менша.

Аналіз публікацій по проблемі. Дослідженням класифікації інновацій присвячено праці багатьох зарубіжних та українських вчених, таких як Ю.М. Бажал [1], О.І. Волков [2], В.Г. Воронкова [3], А. Госнар [4], А.П. Гречан [2], М.П. Денисенко [2], П.Н. Завлін [5], М.А. Йохна [6], А.К. Казанцев [5], Р.С. Косцик [7], Л.Е. Мінделі [5], Г. Менш [8], А.І. Пригожин [9], Н.М. Сиротинська [10], В.В. Стадник [6], Д.М. Степаненко [11], Л.І. Федулова [12], Й. Шумпетер [13]. Проте, питання виокремлення інновацій за різними ознаками досі залишаються дискусійними та потребують подальших досліджень, зокрема питання поділу інновацій за рівнем новизни.
Формування цілей дослідження. Метою роботи є проаналізувати різні підходи щодо класифікації інновацій за рівнем новизни та визначити єдиний підхід, що сприятиме прискоренню їх аналізу для управлінських цілей.

Виклад основних результатів та їх обгрунтування. На сучасний етап економічного розвитку України суттєво впливають фактори інтеграції країни до європейського суспільства. Це вимагає від вітчизняних виробників істотного поліпшення якості продукції, відповідності вироблених товарів міжнародним стандартам, їх конкурентоспроможності. Зазначені тенденції інтеграції гальмуються об'єктивними обставинами: більшість вітчизняних підприємств застосовує застарілі технології та обладнання, мають недостатню кількість кваліфікованих працівників. Для здолання перелічених перешкод потрібні принципово нові підходи, зокрема: сучасні технології, орієнтація виробництва на кінцевого споживача, розвинута мережа менеджменту та нові форми організаційно-виробничої діяльності. Першочергову роль при цьому відіграють інноваційні процеси, які спроможні у найкоротші терміни провести необхідні зміни на 
всіх ділянках виробничого процесу, починаючи 3 правильного визначення цілей інноваційного проекту, оптимального шляху його реалізації та закінчуючи високо прибутковістю виробленої продукції .

Ефективність впровадження інноваційних проектів значним чином залежить від правильного визначення пріоритетності кінцевої мети та раціонального використання наявних матеріальних, трудових та фінансових ресурсів. У зв'язку з цим виникає необхідність визначення оптимального інноваційного впровадження. На даний час розподіл інновацій за різними ознаками має досить розгалужений характер, їх класифікація, в залежності від методів дослідження, в окремих випадках має досить суб'єктивне трактування.

В сучасних економічних умовах України найбільш поширеною формою інновацій $є$ впровадження нових методів виробництва. Їх класифікація за рівнем новизни також достатньо різноманітна. Дослідження вітчизняних та іноземних науковців щодо класифікації інновацій за рівнем новизни нерідко мають неоднозначне тлумачення. Враховуючи викладене, на даний час виникає необхідність проведення уніфікації класифікації інновацій за рівнем новизни, яка дозволить в сучасних економічних умовах нашої країни найбільш ефективно використовувати інноваційні проекти та, відповідно, прискорить процес економічного розвитку України та інтеграції до Європейського Союзу.

У процесі дослідження використано такі наукові методи як аналіз, синтез та наукова абстракція - 3 метою уточнення економічних категорій дослідження, а також метод логічного узагальнення та класифікації - у ході вивчення існуючих підходів щодо класифікацій інновацій.

Як відомо, австрійський вчений Й. Шумпетер визначив поняття «інновація» як «нова комбінація», зокрема він виділив п'ять випадків: виготовлення невідомого блага, впровадження нового методу виробництва, освоєння нового ринку збуту, отримання нового джерела сировини або напівфабрикатів та проведення нової реорганізації [13, с. 158-159].

Дещо ширше поняття «інновація» розкрив німецький дослідник Г. Менш, який врахував рівень новизни інновацій. Г.Менш вперше поділив інновації на «базові», «поліпшуючі» та «псевдоінновації» [8]. На його думку, базові інновації - це такі, що змінюють техніко - технологічний рівень виробництва, дозволяють створювати принципово нові товари та послуги. Поліпшуючі інновації мають дещо менший рівень новизни, а псевдоінновації характеризують незначні удосконалення якості товару або послуги, при яких не змінюється техніко - технологічний рівень виробництва.

На сьогодні існує більше 50 класифікацій інновацій за різними ознакам, найбільш поширені: за видами об'єкта (продуктові, процесні, організаційні, маркетингові), за роллю в реалізації цілей (поліпшувальні, стратегічні), за значенням для реального напрямку діяльності (базисні, модифікувальні, псевдоінновації), за місцем в системі підприємства («на вхо- ді» в підприємство, «на виході» 3 підприємства, інновації структури підприємства), за місцем діяльності (технологічні, виробничі, економічні, торговельні, соціальні, управлінські, інфраструктурні, культурні, політичні, комплексні, екологічні, інформаційні), за інтенсивністю інноваційних змін (нульового порядку, першого порядку, другого порядку, третього порядку, четвертого порядку, п'ятого порядку, шостого порядку, сьомого порядку), за рівнем об'єктивного та суб'єктивного сприйняття (абсолютна новизна, відносна новизна, умовна новизна), за причинами виникнення (реактивні, стратегічні), за географічним чинником (у світовому масштабі, для країни, для регіону, для галузі, для підприємства), за рівнем новизни (радикальні поліпшувальні), за частотою застосування (разові, повторювальні), за напрямом реалізації (для внутрішнього застосування на підприємстві, для накопичення на підприємстві, призначені для продажу), за формою (винаходи, патенти, раціоналізаторські пропозиції, ноу-хау, товарні знаки, торгові марки, емблеми, нові документи, що описують технологічні, виробничі, управлінські процеси, конструкції, структури та методи), за рівнем планування (заплановані, незаплановані), за суб'єктом створення (розроблені на підприємстві, розроблені у ВН3, розроблені у технопарку, розроблені у технополісі, розроблені у науковому парку, розроблені у інноваційному інкубаторі, розроблені фізичною особою тощо), за швидкістю поширення (швидкі, повільні), за характером поширення (рівномірні, згасаючі, наростаючі, стрибкоподібні), за масовістю використання (масові, обмежені), за результативністю (високо результативні, середньо результативні, низько результативні), за новизною місця впровадження (існуюча галузь, нова галузь), за характером задоволення потреб споживачів (для задоволення існуючих потреб, для задоволення новостворених потреб), за призначенням (цивільні, військові), по відношенню до свого попередника (замінюючі, скасовуючі, зворотні, відкриваючі, ретроінновації) та інші. [1, с.40-41, с.54; 2, с.47-48; 3, c.421; 4, c.11-12; 5, c. $20 ; 6$, c. $25-27 ; 7$, c. 190,$192 ; 8 ; 9$, c.39-46, 51; 10, c. $317-318 ; 11$, c. $74 ; 12$, c. $40 ; 14$, c. $9-10 ; 15$, c. $15 ; 16$, c. $25 ; 17$, c. $20,83-84]$.

Ми вважаємо, що з одного боку такий детальний поділ дозволяє точніше класифікувати окремі інновації, проте з іншого боку ускладнює аналіз дублюючи інновації за однією ознакою, використовуючи лише різні синонімічні терміни.

В даній статті ми ставимо за мету поєднати значну кількість класифікацій інновацій, в основі яких лежить рівень новизни. Так, російський науковець А.І. Пригожин поділив інновації по відношенню до свого попередника на замінюючі, скасовуючі, зворотні, відкриваючі та ретроінновації. Замінюючі інновації передбачають повне усунення застарілого засобу, забезпечуючи тим самим більш ефективне виконання відповідних функцій. Скасовуючі - виключають виконання будь-якої операції, випуск будьякого виробу та не замінюють їх новими (наприклад: скасування певної форми звітності). Зворотні - коли після використання інновації виявляється пї 
неспроможність або невідповідність певним умовам і доводиться повертатися до попереднього (згідно рішення Гідрометцентру СРСР почали вимірювати атмосферний тиск в гектопаскалях, а потім повернулися до міліметрів ртутного стовпчика). Відкриваючі тобто такі, що утворюють засоби, що не мали порівняльних функціональних попередників (винахід радіо або телебачення). Ретроінновації - відтворюють на сучасному рівні старі прилади та матеріали (парусне судноплавство та дирижабль) $[9$, с.41-46, 51]. На наш погляд така класифікація є тотожною з класифікацією Г. Менша, де: відкриваючі - базисні; замінюючі - поліпшуючі; скасовуючі, зворотні та ретроінновації псевдоінновації.

За роллю в реалізації цілей організації українська дослідниця Л.І. Федулова виокремлює поліпшувальні інновації, що проводяться в межах розвитку й удосконалення напрямів діяльності, та стратегічні інновації, що створюють нові напрями діяльності або забезпечують успішне функціонування існуючих напрямів на тривалий час [12, с.40]. Під нашим кутом зору спостерігаємо аналогію з класифікацією Г. Менша, де поліпшувальні - поліпшуючі, а стратегічні базові.

Українські вчені М.А. Йохна та В.В. Стадник надають класифікацію за причинами виникнення інновацій, де реактивні - це інновації, що забезпечують виживання та конкурентоспроможність фірми на ринку, виникаючі як реакція на нові перетворення, що здійснюються конкурентами; стратегічні - інновації, впровадження яких має випереджувальний характер 3 метою отримання вирішальних конкурентних переваг у перспективі [6, с.26-27]. На нашу думку зміст класифікаційної ознаки при цьому один й той самий, а також є аналогічними поняття видів інновацій, різниця тільки у використанні різної термінології: «поліпшувальні» - «реактивні». Ми вважаємо, що і в цьому випадку проявляється аналогія 3 класифікацією Г. Менша, а саме: реактивні - поліпшуючі, а стратегічні - базові.

Л.І. Федулова, за значенням для реального напряму діяльності, поділяє інновації на базисні (фундаментальні), які радикально змінюють сталий або формують новий напрям діяльності; модифікувальні, які здійснюються в межах удосконалення й розвитку базисних; псевдоінновації, як зовнішні неістотні зміни продуктів або процесів, що не мають принципової новизни і не створюють жодних додаткових переваг для споживачів [12, с.40]. На нашу думку такий поділ $€$ тотожним $з$ класифікацією Г. Менша, де модифіковані - поліпшуючі, а базисні - базові.

Ряд вчених, таких як Д.М. Степаненко [11, с.74], Р.С. Косцик [7, с.190, 192], О.І. Волков, М.П. Денисенко, А.П. Гречан [2, с.47-48], А.І. Пригожин [9, с.39-41, 51], Л.І. Федулова [12, с.40], Ю.М. Бажал [1, с.54], А. Госнар [4, с.11-12,] П.Н. Завлін, А.К. Казанцев, Л.Е. Мінделі [5, с.20] поділяють інновації за рівнем новизни на радикальні, системні, модифіковані та псевдоінновації. Проте, ми вважаємо що такий поділ за своїм змістом відповідає класифікації Г. Менша, де радикальні є базові, а системні та модифіковані - поліпшуючі.

Наша співвітчизниця В.Г. Воронкова поділяє інновації залежно від значущості на великі, середні та дрібні. Великі інновації грунтуються на відкриттях та великих винаходах і формують нове покоління техніки. Середні інновації створюють нові моделі вже існуючої техніки та розширюють сферу їх застосування. Дрібні інновації покращують виробничі або споживальні параметри існуючої техніки на основі дрібних винаходів та раціоналізаторських пропозицій [3, c.421]. Під нашим кутом зору такий поділ схожий 3 поділом Г. Менша де великі інновації можливо віднести до базових, середні до поліпшуючих, а дрібні до псевдоінновацій.

Н.М. Сиротинська класифікує промислові інновації за обсягом новизни на радикальні, покращувальні та псевдоінновації [10, с.317-318]. На нашу думку зміст таких класифікацій є однаковим 3 поділом Г. Менша, різниця лише у вибраній термінології.

М.А. Йохна, В.В. Стадник, О.І. Волков, М.П. Денисенко, А.П. Гречан за інтенсивністю інноваційних змін виокремлюють:

« - інновації нульового порядку (регенерування вихідних властивостей) - цільова зміна, що зберігає й оновлює існуючі функції виробничої системи чи їі частини, наприклад: нова фарба для автомобіля;

- інновації першого порядку (кількісна зміна) - просте цільове пристосування до кількісних вимог при збереженні функцій виробничої системи чи іiі частини, наприклад: розширення ринків збуту;

- інновації другого порядку (перегрупування чи організаційні зміни) - прості організаційні зміни, наприклад: поділ відділу маркетингу на підрозділ досліджень ринку і підрозділ стимулювання збуту;

- інновації третього порядку (адаптаційні зміни) - зміни, що викликані взаємним пристосуванням елементів виробничої системи, наприклад: адаптація допоміжних процесів до змін в основних виробничих процесах у зв'язку з удосконаленням випуску продукції;

- інновації четвертого порядку (новий варіант) - найпростіша якісна зміна, що перевищує межі простих адаптивних змін, наприклад: оснащення певної моделі автомобіля потужнішим двигуном;

- інновації п’ятого порядку («нове покоління») - змінюються всі або більшість функціональних властивостей виробничої системи, але базова структурна концепція зберігається, наприклад: впровадження програмного управління верстатом;

- інновації шостого порядку (новий «вид») якісна зміна функціональних властивостей виробничої системи чи їі частини, змінюється вихідна концепція, але функціональний принцип залишається, наприклад: стільниковий зв'язок;

- інновації сьомого порядку (новий «рід») - корінна зміна функціональних властивостей виробничої системи або іiі частини, що змінює іiі основний функціональний принцип» [6, с.25-26; 2, с.47-48]. Під нашим кутом зору, ця класифікація більш детально класифікує інновації у розумінні Г. Менша, де інновації сьомого порядку - базові, інновації з першого по шостий 
порядок - поліпшуючі, а інновації нульового порядку - псевдоінновації.

М.А. Йохна та В.В. Стадник за рівнем об'єктивного та суб' єктивного сприйняття, групують інновації:

- 3 абсолютною новизною, при відсутності аналогів даної новації; з відносною новизною, коли інновацію було застосовано на інших об'єктах або ж здійснено оновлення одного з елементів виробу системи в процесі поточної модернізації;

- з умовною новизною, коли виникає як наслідок незвичайного сполучення раніше відомих елементів;

- 3 суб’єктивною новизною, для певних споживачів, які раніше не були знайомі з даним продуктом [6, с.26-27]. На нашу думку інновації з абсолют- ною новизною $є$ базовими, 3 відносною новизною поліпшуючі, з умовною новизною - псевдоінновації.

Ю.М. Бажал поділяє інновації за новизною місця впровадження для існуючої галузі (виробництва) та для нової галузі (виробництва) [1, с.41]. Ми вважаємо такий поділ доцільним, коли в майбутньому буде спостерігатися тенденція до збільшення інновацій для нових галузей (виробництв), проте в загальному вигляді можливо говорити про поліпшуючі інновації у разі впровадження інновацій для існуючої галузі, та про базові інновації у разі впровадження для нової галузі.

Проаналізувавши зазначені класифікації різних дослідників, можемо визначити, що в їх основі лежить підхід запропонований Г. Меншем щодо поділу інновацій за рівнем новизни (рис. 1).

По відношенню до свого попередника (А.І. Пригожин)

За роллю в реалізації цілей

(Л.І. Федулова)

За причинами виникнення

(М.А. Йохна, В.В. Стадник)

За значенням для реального напряму діяльності

(Ю.М. Бажал, В.Г. Воронкова, П.Н. Завлін, А.І. Казанцев, Л.Е. Мінделі, А.І. Пригожин,

Н.М. Сиротинська, Л.І. Федулова)

За рівнем новизни

(О.І. Волков, М.П. Денисенко, А. Госнар, А.П. Гречан, Д.М. Степаненко, Р.С. Косцик)

За інноваційним потенціалом

(А.І. Пригожин)

Залежно від значущості

(В.Г. Воронкова)

За обсягом новизни

(Н.М. Сиротинська)

За інтенсивністю інноваційних змін

(М.П. Денисенко, А.П. Гречан, М.А. Йохна, В.В. Стадник)

За рівнем об'єктивного та суб'єктивного прийняття

(М.А. Йохна, В.В. Стадник)

За новизною місця впровадження

(Ю.М. Бажал)

Рис. 1. Спорідненість існуючих класифікацій інновацій з класифікацісю Г. Менша за рівнем новизни*

*Розроблено автором на підставі [1, с.40-41, с.54; 2, с.47-48; 3, с.421; 4, с.11-12; 5, с.20; 6, с.25-27;

7, c. 190,$192 ; 8 ; 9$, c.39-46, 51; 10, c.317-318; 11, c.74; 12, c.40]. 
Отже в даній статті ми дослідили значну кількість класифікацій інновацій, в основі яких лежить рівень новизни. Однак, слід зазначити, що одна інновація може класифікуватися не тільки за рівнем новизни, а й за іншими ознаками. А оскільки класифікація інновацій за рівнем новизни не дає можливості класифікувати інновації за іншими важливими ознаками, то вважаємо необхідним надати загальну класифікацію інновацій (табл. 1), що дозволить проводити повний всебічний аналіз інновацій.

Таблиця 1

Загальна класифікація інновацій*

\begin{tabular}{|c|c|c|}
\hline $\begin{array}{c}\text { Критерій } \\
\text { класифікації }\end{array}$ & Види інновацій & Джерело \\
\hline За рівнем новизни & $\begin{array}{l}\text { - базові; } \\
\text { - поліпшуючі; } \\
\text { - псевдоінновації. }\end{array}$ & $\begin{array}{l}\text { Г. Менш [8], А. Госнар [4, с.11-12], } \\
\text { Ю.М. Бажал [1, с.41, 54], } \\
\text { Л.І. Федулова [12, с.40], } \\
\text { В.Г. Воронкова [3, с.421], } \\
\text { Н.М. Сиротинська [10, с.317-318], П.Н. Завлін, } \\
\text { А.К. Казанцев, Л.Е. Мінделі [5, с.20], } \\
\text { А.І. Пригожин [9, с.39-46, 51], } \\
\text { М.А. Йохна та В.В. Стадник [6, с.26-27], } \\
\text { Д.М. Степаненко [11, с.74], } \\
\text { Р.С. Косцик [7, с.190, 192], } \\
\text { О.І. Волков, М.П. Денисенко, А.П. Гречан [2, } \\
\text { с.47-48]. }\end{array}$ \\
\hline За видом об’єкта & $\begin{array}{l}\text { - продуктові; } \\
\text { - процесні; } \\
\text { - організаційні; } \\
\text { - маркетингові. }\end{array}$ & $\begin{array}{l}\text { Керівництво Осло [18, с.21-22], } \\
\text { Л.І. Федулова [12, с.40], Д.М. Степаненко [11, } \\
\text { с. } 74], \\
\text { Р.С. Косцик [7, с.190], } \\
\text { В.П. Соловйов, Г.І. Кореняко, В.М. Головатюк } \\
\text { [14, с.9-10], } \\
\text { Н.М. Сиротинська [10, с.317-318]. }\end{array}$ \\
\hline $\begin{array}{l}\text { За місцем в системі } \\
\text { підприємства }\end{array}$ & $\begin{array}{l}\text { - «на вході» в підприємство; } \\
\text { - «на виході» } 3 \text { підприємства; } \\
\text { - інновації структури підприємства. }\end{array}$ & $\begin{array}{l}\text { Л.І. Федулова [12, с.41], } \\
\text { М.А. Йохна та В.В. Стадник [6, с.25], } \\
\text { Н.М. Сиротинська [10, с.317-318], О.І. Волков, } \\
\text { М.П. Денисенко, А.П. Гречан [2, с.47-48]. }\end{array}$ \\
\hline $\begin{array}{l}\text { За змістом } \\
\text { діяльності }\end{array}$ & $\begin{array}{l}\text { - технологічні; } \\
\text { - виробничі; } \\
\text { - економічні; } \\
\text { - торговельні; } \\
\text { - соціальні; } \\
\text { - управлінські; } \\
\text { - інфраструктурні; } \\
\text { - культурні; } \\
\text { - політичні; } \\
\text { - комплексні; } \\
\text { - екологічні; } \\
\text { - інформаційні. }\end{array}$ & $\begin{array}{l}\text { Л.І. Федулова [12, с.41], Д.М. Степаненко [11, } \\
\text { с.74], } \\
\text { П.С. Харів [15, с.15], } \\
\text { О.Л. Богашко [16, с.25], } \\
\text { М.А. Йохна та В.В. Стадник [6, с.25], Ю. М. } \\
\text { Бажал [1, с.41, 54, 125], } \\
\text { В.Г. Воронкова [3, с.418, 420-421], Н.М. Сиро- } \\
\text { тинська [10, с.317-318], П.Н. Завлін, } \\
\text { А.К. Казанцев, Л.Е. Мінделі [5, с.19], } \\
\text { А.І. Пригожин [9, с.33-39, 51]. }\end{array}$ \\
\hline $\begin{array}{l}\text { За причинами ви- } \\
\text { никнення }\end{array}$ & $\begin{array}{l}\text { - реактивні; } \\
\text { - стратегічні. }\end{array}$ & $\begin{array}{l}\text { М.А. Йохна та В.В. Стадник [6, с.26-27], Н.М. } \\
\text { Сиротинська [10, с.317-318]. }\end{array}$ \\
\hline $\begin{array}{l}\text { За географічним } \\
\text { чинником }\end{array}$ & $\begin{array}{l}\text { - у світовому масштабі; } \\
\text { - для країни; } \\
\text { - для регіону; } \\
\text { - для галуззі; } \\
\text { - для підприємства. }\end{array}$ & $\begin{array}{l}\text { Д.М. Степаненко [11, с.74], } \\
\text { Р.С. Косцик [7, с.191-193], } \\
\text { Н.М. Сиротинська [10, с.317-318], П.Н. Завлін, } \\
\text { А.К. Казанцев, Л.Е. Мінделі [5, с.19]. }\end{array}$ \\
\hline $\begin{array}{l}\text { За частотою } \\
\text { застосування }\end{array}$ & $\begin{array}{l}\text { - разові; } \\
\text { - повторювальні. }\end{array}$ & $\begin{array}{l}\text { Д.М. Степаненко [11, с.74]; } \\
\text { Р.С. Косцик [7, с.191], } \\
\text { Н.М. Сиротинська [10, с.317-318]. }\end{array}$ \\
\hline $\begin{array}{l}\text { За напрямом реалі- } \\
\text { зації }\end{array}$ & $\begin{array}{l}\text { - для внутрішнього застосування на } \\
\text { підприємстві; } \\
\text { - для накопичення на підприємстві; } \\
\text { - призначені для продажу. }\end{array}$ & $\begin{array}{l}\text { Д.М. Степаненко [11, с.74], } \\
\text { Р.С. Косцик [7, с.190], } \\
\text { Н.М. Сиротинська [10, с.317-318]. }\end{array}$ \\
\hline
\end{tabular}


Продовження табл.1

\begin{tabular}{|c|c|c|}
\hline $\begin{array}{c}\text { Критерій } \\
\text { класифікації }\end{array}$ & Види інновацій & Джерело \\
\hline За формою & $\begin{array}{ll}\text { - } & \text { винаходи, патенти; } \\
\text { - } & \text { раціоналізаторські пропозиції; } \\
\text { - } & \text { ноу-хау; } \\
\text { - } & \text { товарні знаки, торгові марки, } \\
& \text { емблеми; } \\
\text { - } & \text { нові документи, що описують } \\
& \text { технологічні, виробничі, } \\
& \text { управлінські процеси, } \\
& \text { конструкції, структури та мето- } \\
& \text { ди. }\end{array}$ & $\begin{array}{l}\text { Д.М. Степаненко [11, с.74], } \\
\text { Р.С. Косцик [7, с.191], } \\
\text { Н.М. Сиротинська [10, с.317], П.Н. Завлін, } \\
\text { А.К. Казанцев, Л.Е. Мінделі [5, с.20]. }\end{array}$ \\
\hline $\begin{array}{l}\text { За рівнем } \\
\text { планування }\end{array}$ & $\begin{array}{ll}\text { - } & \text { заплановані; } \\
\text { - } & \text { незаплановані. } \\
\end{array}$ & Р.С. Косцик [7, с.190]. \\
\hline $\begin{array}{l}\text { За суб'єктом } \\
\text { створення }\end{array}$ & $\begin{array}{ll}\text { - } & \text { розроблені на підприємстві; } \\
\text { - } & \text { розроблені у ВНЗ; } \\
\text { - } & \text { розроблені у технопарку; } \\
\text { - } & \text { розроблені у технополісі; } \\
\text { - } & \text { розроблені у науковому парку; } \\
\text { - } & \text { розроблені в інноваційному } \\
& \text { інкубаторі; } \\
\text { - } & \text { розроблені фізичною особою } \\
& \text { тощо; }\end{array}$ & Р.С. Косцик [7, с.191-192]. \\
\hline $\begin{array}{l}\text { За швидкістю } \\
\text { поширення }\end{array}$ & $\begin{array}{ll}\text { - } & \text { швидкі; } \\
\text { - } & \text { повільні; } \\
\end{array}$ & Р.С. Косцик [7, с.191]. \\
\hline $\begin{array}{l}\text { За характером } \\
\text { поширення }\end{array}$ & $\begin{array}{ll}\text { - } & \text { рівномірні; } \\
\text { - } & \text { згасаючі; } \\
\text { - } & \text { наростаючі; } \\
\text { - } & \text { стрибкоподібні } \\
\end{array}$ & $\begin{array}{l}\text { запропоновано автором на підставі Р.С. Косцик } \\
\text { [7, с.191], } \\
\text { П.Н. Завлін, А.К. Казанцев, Л.Е. Мінделі [5, } \\
\text { с.19]. }\end{array}$ \\
\hline $\begin{array}{l}\text { За масовістю } \\
\text { використання }\end{array}$ & $\begin{array}{ll}\text { - } & \text { масові; } \\
\text { - } & \text { обмежені. }\end{array}$ & $\begin{array}{l}\text { P.С. Косцик [7, с.192], } \\
\text { А.I. Пригожин }[9, \text { с. } 47,49] .\end{array}$ \\
\hline $\begin{array}{l}\text { За } \\
\text { результативністю }\end{array}$ & $\begin{array}{ll}\text { - } & \text { високо результативні; } \\
\text { - } & \text { середньо результативні; } \\
\text { - } & \text { низько результативні. } \\
\end{array}$ & $\begin{array}{l}\text { Р.С. Косцик [7, с.192-193], } \\
\text { А.І. Пригожин [9, с.47-48]. }\end{array}$ \\
\hline $\begin{array}{l}\text { За характером } \\
\text { задоволення потреб } \\
\text { споживачів }\end{array}$ & $\begin{array}{l}\text { - } \quad \text { для задоволення існуючих по- } \\
\text { треб; } \\
\text { - } \quad \text { для задоволення новостворених } \\
\text { потреб. }\end{array}$ & Н.М. Сиротинська [10, с.317]. \\
\hline За призначенням & $\begin{array}{ll}\text { - } & \text { цивільні; } \\
\text { - } & \text { військові. } \\
\end{array}$ & $\begin{array}{l}\text { запропоновано автором на підставі } \\
\text { Б. Санто }[17, \text { с. } 20,83-84] .\end{array}$ \\
\hline
\end{tabular}

* Сформовано та уточнено автором на підставі джерел $[1$, с.40-41, с.54, 125; 2, с.47-48; 3, с.418, 420421; 4, c.11-12; 5, c.19-20; 6, c.25-27; 7, c.190-193; 8; 9, c.33-48, 51; 10, c.317-318; 11, c.74; 12, c.40-41; 14, c.9-10; 15 , c. $15 ; 16$, c. $25 ; 17$, c. $20,83-84 ; 18$, c. $21-22]$.

На нашу думку, надана таблиця загальної класифікації інновацій дозволяє чітко визначати будь-яку інновацію за різними ознаками, та дозволяє проводити повний аналіз, що в свою чергу сприятиме швидшому прийняттю управлінських рішень.

Висновки та перспективи подальших досліджень. Проаналізувавши дослідження вітчизняних та зарубіжних авторів з питання класифікації інновацій за роллю в реалізації цілей, за значенням для реального напряму діяльності, за інтенсивністю інноваційних змін, за рівнем об'єктивного сприйняття, за причинами виникнення, за рівнем новизни, за інноваційним потенціалом, за новизною місця впровадження та за характером до свого попередника встановле- но, що в основі зазначених класифікацій лежить класифікація Г. Менша за рівнем новизни, що поділяє інновації на базові, поліпшуючі та псевдоінновації.

Враховуючи викладене, вважаємо, що система поділу інновацій, яка запропонована Г. Меншем, $є$ найбільш уніфікованою та дозволяє використовувати iii на всіх етапах життєвого циклу інновацій. Уніфікована класифікація Г. Менша прискорює визначення рівня інновації та дозволяє приймати оперативні та грунтовні організаційні і управлінські рішення стосовно інноваційної діяльності. Поділ інновацій на базові, поліпшуючі та псевдоінновації потребує подальшого дослідження, що дозволить чітко розмежувати ïx за значимістю на кожному етапі впровадження, 
надасть пріоритетність використання базових і поліпшуючих інновацій та, відповідно, визначить шляхи удосконалення технологічних і технічних процесів.

Оскільки класифікація інновацій за рівнем новизни не дає можливості класифікувати інновації за іншими важливими ознаками, то автором запропонована загальна класифікацій інновацій. Надана загальна класифікація інновацій дозволяє класифікува- ти інновації за різними ознаками, а саме: за рівнем новизни, за видом об'єкта, за місцем в системі підприємства, за змістом діяльності, за причинами виникнення, за географічним чинником, за частотою застосування, за напрямом реалізації, за формою, за рівнем планування, за суб' єктом створення, за швидкістю поширення, за масовістю використання, за результативністю, за характером задоволення потреб споживачів, та за призначенням.

\section{Лiтература}

c.

1. Бажал Ю.М. Економічна теорія технологічних змін : навчальний посібник. Київ : Заповіт, 1996. 240

2. Економіка й організація інноваційної діяльності : підручник. О.І. Волков, М.П. Денисенко, А.П. Гречан [та ін.] ; під ред. проф. О.І. Волкова, проф. М.П. Денисенка. Друге видання. Київ : Центр учбової літератури, 2005. $424 \mathrm{c}$.

3. Воронкова В.Г. Теоретичні засади управління інноваційним процесом в Україні. Вісник Національного університету Львівська політехніка. Проблеми економіки та управління. 2008. № 628. С. 417-423.

4. Gosnar Ana. The Classification of Innovations: the Case of Apple Inc. University of Ljubljana, Faculty of Economics, 2012. 64 p. Retrieved from: http://www.cek.ef.uni-lj.si/magister/gosnar795-B.pdf

5. Завлин П.Н. Инновационный менеджмент : справ. пособие / под ред. П.Н. Завлина, А.К. Казанцева, Л.Э. Миндели. Изд. 2-е, переработ. и доп. М. : ЦИСН, 1998. 568 с.

6. Йохна М.А., Стадник В.В. Економіка і організація інноваційної діяльності : навчальний посібник. Київ : Академія, 2005. 400 с.

7. Косцик Р.С. Види інновацій на промислових підприємствах. [Електронний ресурс]. Науковий вісник НЛТУ України. 2012. Вип. 22.02. С.185-194. Режим доступу: http://nbuv.gov.ua/UJRN/nvnltu_2012_22.2 35. (дата звернення 5.07.2018)

8. Mensh G. Statement in Technology: innovation overcome the depression. Cambridge: Mass, 1979. 360 p.

9. Пригожин А.И. Нововведения: стимулы и препятствия. М. : Политиздат, 1989. 271 с. (Социальные проблемы инноватики).

10. Сиротинська Н.М. Види інноваційних підприємств промисловості. Вісник національного університету Львівська політехніка. Менеджмент та підприємництво в Україні: етапи становлення і проблеми розвитку. Львів. Львівська політехніка. 2012. № 727. С.314-319.

11. Степаненко Д.М. Классификация инноваций и ее стандартизация в Республике Беларусь. Вестник БНТУ. 2005. № 5. С.71-75.

12. Федулова Л.І. Інноваційна економіка : підручник. Київ : Либідь, 2006. 480 с.

13. Шумпетер Й. Теория экономического развития. Экономическая мысль запада / пер. с нем: В.С. Автономова, М.С. Любского, А.Ю. Чепуренко. М. : Прогресс, 1982. 455 с.

14. Соловйов В.П., Кореняко Г.І., Головатюк В.М. Інноваційний розвиток регіонів: питання теорії та практики : монографія. Київ : Фенікс, 2008. 224 с.

15. Харів П.С. Інноваційна діяльність підприємства та економічна оцінка інноваційних процесів : монографія. Тернопіль : Економічна думка, 2003. 326 с.

16. Богашко О.Л., Еволюція теоретичних підходів до інноваційного розвитку в економічній науці. Вісник Бердянського університету менеджменту і бізнесу. 2013. № 2. С. 23-29.

17. Санто Б. Инновация как средство экономического развития. М. : Прогресс, 1990. 296 с.

18. Руководство Осло. Рекомендации по сбору и анализу данных по инновациям. [Електронний ресурс]. Третье издание. Перевод с английского. М., 2006. 196 с. Режим доступу: http://rii-vuz.extech.ru/doc/oslo.pdf (дата звернення 5.07.2018)

Стаття надійшла 11.07.2018

Стаття прийнята до друку 26.07.2018

Доступно в мережі Internet 17.10.2018

\section{Колищук E.B.} аспирант

кафедра экономики та международных економических отношений

Черкасский национальний университет имени Богдана Хмельницкого

бульвар Шевченко, 81, Черкассы, Черкасская область, 18000

E-mail: olenakolischuk@gmail.com

\section{АНАЛИЗ КЛАССИФИКАЦИЙ ИННОВАЦИЙ ПО УРОВНЮ НОВИЗНЫ}

В статье рассмотрены виды классификаций инноваций в зависимости от уровня новизны. Проанализированы основные подходы классификации инноваций отечественными и зарубежными 
исследователями, такими как Ю.М. Бажал, О.И. Волков, В.Г. Воронкова, А. Госнар, А.П. Гречан, М.П. Денисенко, П.Н. Завлин, М.А. Йохна, А.К. Казанцев, Р.С. Косцик, Л.Э. Миндели, Г. Менш, А.И. Пригожин, Н.М. Сиротинская, В.В. Стадник, Д.М. Степаненко, Л.И. Федулова и Й. Шумпетер. В частности, рассмотрены классификации инноваций по роли в реализации целей, по значению для реального направления деятельности, по интенсивности инновационных изменений, по уровню объективного восприятия, по причинам возникновения, по уровню новизны, по инновационному потенциалу, по новизне места внедрения и по характеру к своему предшественнику. Определены основные фракторы, которые легли в основу упомянутых классификаций, аргументирован вывод, что в основе перечисленных видов классификаций находится модель классификации, предложенная немецким ученым Г. Меншем, которая является наиболее объективной и унифицированной и позволяет использовать ее на всех этапах жизненного цикла инноваций с целью ускорения процесса определения уровней инноваций в зависимости от их новизны и возможности практического воплощения. Аргументирован вывод о том, что предложенная Г. Меншем классификация требует дальнейшего исследования с целью более четкого разграничения инноваций по значимости на каждом этапе внедрения, приоритетности использования и определения путей совершенствования научно-технических, технологических, организационных, маркетинговых, экономических, информационных, социальных и других процессов.

Ключевые слова: инновация, классификация инноваций, классификационный признак, базовые инновации, улучшающие инновации, псевдоинновации.

\author{
Kolishchuk O. \\ Postgraduate \\ Department of Economics and International Economic Relations, \\ The Bohdan Khmelnytsky National University of Cherkasy \\ 81 Shevchenko Boulevard, Cherkasy, Cherkasy region, 18000 \\ E-mail: olenakolischuk@gmail.com
}

\title{
THE ANALYSIS OF INNOVATION CLASSIFICATIONS BY THE NOVELTY LEVEL
}

The article considers different types of innovation classifications depending on the novelty level. The main approaches to the classification of innovations by domestic and foreign researchers such as Yu.M. Bazhal, O.I. Volkov, V.H. Voronkova, A. Gosnar, A.P. Hrechan, M.P. Denysenko, P.N. Zavlin, M.A. Yokhna, A.K. Kazantsev, R.S. Kostsyk, L.E Mindeli, G. Mensh, A.Y. Pryhozhyn, N.M. Syrotynska, V.V. Stadnyk, D.M. Stepanenko, L.I. Fedulova and Y. Schumpeter has been analyzed here. In particular, we have reviewed the classification of innovations by their role in the implementation of goals, significance for the actual activity direction, intensity of innovative changes, level of objective perception, reasons of origin, innovation level and potential, novelty of the implementation place and by its predecessor character. The main factors that formed the basis of the mentioned classifications have been defined. We have concluded that the classification model suggested by the German scientist G. Mensch is the basis of the above mentioned classification types, which is the most objective and unified and can be used at all stages of the life cycle of innovations in order to accelerate the process of defining the innovation levels, depending on their novelty and the possibility of practical implementation. We have come to the conclusion that the classification suggested by $\mathrm{G}$. Mensh requires further research with the purpose of making more detailed innovation differentiation based on its importance at each stage of implementation, priority of use and determination of ways to improve scientific, technical, technological, organizational, marketing, economic, informational, social and other processes.

Keywords: innovation, classification of innovations, classification criteria, basic innovations, improving innovation, pseudo-innovation.

\section{References}

1. Bazhal, Yu. M. (1996). Ekonomichna teoriia tekhnolohichnykh zmin. Kyiv: Zapovit.

2. Volkov, O. I., Denysenko, M. P., \& Hrechan, A. P. (2005). Ekonomika y orhanizatsiia innovatsiinoi diialnosti (2nd ed.) (O. I. Volkov \& M. P. Denysenko, Eds.). Kyiv: Tsentr uchbovoi literatury.

3. Voronkova, V. H. (2008). Teoretychni zasady upravlinnia innovatsiinym protsesom v Ukraini. Visnyk Natsionalnoho Universytetu Lvivska Politekhnika. Problemy Ekonomiky Ta Upravlinnia, (628), 417-423.

4. Gosnar, A. (2012). The Classification of Innovations: The Case of Apple Inc. Retrieved from http://www.cek.ef.uni-lj.si/magister/gosnar795-B.pdf 
5. Zavlin, P. N. (1998). Innovatsionnyiy menedzhment (2nd ed.) (P. N. Zavlin, A. K. Kazantsev, \& L. E. Mindeli, Eds.). Moskva: TsISN.

6. Yokhna, M. A., \& Stadnyk, V. V. (2005). Ekonomika i orhanizatsiia innovatsiinoi diialnosti. Kyiv: Akademiia.

7. Kostsyk, R. S. (2012). Vydy innovatsii na promyslovykh pidpryiemstvakh. Naukovyi Visnyk NLTU Ukrai$n y$, (22.02), 185-194. Retrieved July 05, 2018, from http://nbuv.gov.ua/UJRN/nvnltu_2012_22.2_35

8. Mensh, G. (1979). Statement in Technology: Innovation overcome the depression. Cambridge: Mass.

9. Prigozhin, A. I. (1989). Novovvedeniya: Stimulyi i prepyatstviya. Moskva: Politizdat.

10. Syrotynska, N. M. (2012). Vydy innovatsiinykh pidpryiemstv promyslovosti. Visnyk Natsionalnoho Universytetu Lvivska Politekhnika. Menedzhment Ta Pidpryiemnytstvo v Ukraini: Etapy Stanovlennia I Problemy Rozvytku, (727), 314-319.

11. Stepanenko, D. M. (2005). Klassifikatsiya innovatsiy i ee standartizatsiya v Respublike Belarus. Vestnik $B N T U,(5), 71-75$.

12. Fedulova, L. I. (2006). Innovatsiina ekonomika. Kyiv: Lybid.

13. Shumpeter, Y. (1982). Teoriya ekonomicheskogo razvitiya. Ekonomicheskaya myisl zapada (V. S. Avtonomov, M. S. Lyubskiy, \& A. Yu. Chepurenko, Trans.). Moskva: Progress.

14. Soloviov, V. P., Koreniako, H. I., \& Holovatiuk, V. M. (2008). Innovatsiinyi rozvytok rehioniv: Pytannia teorii ta praktyky. Kyiv: Feniks.

15. Khariv, P. S. (2003). Innovatsiina diialnist pidpryiemstva ta ekonomichna otsinka innovatsiinykh protsesiv. Ternopil: Ekonomichna dumka.

16. Bohashko, O. L. (2013). Evoliutsiia teoretychnykh pidkhodiv do innovatsiinoho rozvytku v ekonomichnii nautsi. Visnyk Berdianskoho Universytetu Menedzhmentu I Biznesu, (2), 23-29.

17. Santo, B. (1990). Innovatsiya kak sredstvo ekonomicheskogo razvitiya. Moskva: Progress.

18. Rukovodstvo Oslo. Rekomendatsii po sboru i analizu dannyih po innovatsiyam. (2006). Retrieved July 05 , 2018, from http://rii-vuz.extech.ru/doc/oslo.pdf

Цитування згідно ДСТУ 8302:2015

Received 11 July 2018

Approved 26 July 2018

Available in Internet 17.10.2018

Коліщук О.В. Аналіз класифікацій інновацій за рівнем новизни // Економіка харчової промисловості. 2018. Т. 10, Вип. 3. С. 57-65; doi: 10.15673/fie.v10i3.1062

Cite as APA style citation

Kolishchuk O. (2018). The analysis of innovation classifications by the novelty level. Food Industry Economics, 10(3), 5765; doi: 10.15673/fie.v10i3.1062 